\title{
Ginger Oil
}

National Cancer Institute

\section{Source}

National Cancer Institute. Ginger Oil. NCI Thesaurus. Code C107310.

The essential oil of Zing iber officinale. Ginger oil has been used for digestive health. 